\title{
SOCS-3 antagonises the proliferative and migratory effects of fibroblast growth factor-2 in prostate cancer by inhibition of p44/p42 MAPK signalling
} \author{
Alfred Hobisch ${ }^{1}$ and Zoran Culig \\ Department of Urology, Innsbruck Medical University, Anichstrasse 35, A-6020 Innsbruck, Austria \\ ${ }^{1}$ Department of Urology, General Hospital Feldkirch, A-6800 Feldkirch, Austria \\ (Correspondence should be addressed to Z Culig; Email: zoran.culig@i-med.ac.at)
}

Martin Puhr, Frédéric R Santer, Hannes Neuwirt, Gemma Marcias,

\begin{abstract}
Fibroblast growth factor-2 (FGF-2) is highly expressed in prostate cancer. It promotes tumour progression through multiple pathways including those of signal transducers and activators of transcription factor 3 (STAT3), mitogen-activated protein kinases (MAPKs) and Akt. In previous studies, we have reported that STAT3 phosphorylation inversely correlates with suppressor of cytokine signalling-3 (SOCS-3) expression in prostate cancer cells. Recently, it has become evident that SOCS-3-negative regulation is not only limited to the interleukin-6 (IL-6) receptor. We hypothesised that SOCS-3 interferes with FGF signalling, thus influencing the outcome of its action in prostate cancer cells. For this purpose, we treated DU-145 and LNCaP-IL-6 + cells with increasing concentrations of FGF-2, and verified protein phosphorylation. In the presence of FGF-2, neither STAT3, STAT1, nor Akt could be phosphorylated. Solely the p44/p42 MAPK pathway was activated after FGF-2 stimulation. We show for the first time that SOCS-3 interferes with the FGF-2 signalling pathway by modulating p44 and p42 phosphorylation in prostate cancer cells. Decreased SOCS-3 protein expression results in increased MAPK phosphorylation, whereas SOCS-3 overexpression leads to a decreased cellular proliferation and migration. On the basis of the present results, we propose that SOCS-3 is a novel modulator of FGF-2-regulated cellular events in prostate cancer.
\end{abstract}

Endocrine-Related Cancer (2010) 17 525-538

\section{Introduction}

The fibroblast growth factor (FGF) family consists of 23 members, FGF-1-23. FGFs interact with a family of four tyrosine kinase receptors, FGFR1-4. Many FGFs like FGF-2 have potent mitogenic and angiogenic activity, and have been considered as promoters of tumour growth and angiogenesis (Ropiquet et al. 1999, 2000). FGF-2 has also been linked with an increase in motility and invasiveness of cancer cells (Wesley et al. 2005). Although the growth factor does not contain a signal sequence for secretion, it is secreted and localised in the extracellular matrix of many tissues, and can act in a paracrine or autocrine manner. In addition, FGF-2 also contains a nuclear localisation sequence (Bugler et al. 1991). However, the role of nuclear localisation in the activity of FGF-2 remains unclear.

The expression of FGF-2 is increased in many types of carcinomas including those of prostate (Giri et al. 1999). FGF-2 can bind to all four FGFRs with variable binding affinities for each of them (Ornitz et al. 1996). The receptors consist of an extracellular part with three immunoglobulin-like domains and an intracellular part with a tyrosine kinase domain. FGFR1-3 can be alternatively spliced, which results in different isoforms with altered binding specificities. FGFs and the FGF signalling pathway appear to play not only an important role in the maintenance and growth of the 
normal prostate but also during the development and progression of prostate cancer. The major source of FGFs is the stromal compartment in the normal prostate. A balanced interaction between stromal and epithelial cells through FGFs, which act as paracrine growth factors for epithelial cells, is crucial for normal development and growth of prostate epithelium (Tuxhorn et al. 2002, Ayala et al. 2003, Yang et al. 2008). FGF-2 supports proliferation, migration and invasion in human prostate cancer cellular models (Wesley et al. 2005). Oncogenic events caused by FGF-2, including proliferation and migration, could be in part mediated through heparin affin regulatory peptide/pleiotrophin (Hatziapostolou et al. 2006).

Binding of FGF-2 leads to dimerisation and transphosphorylation of tyrosine residues in the intracellular domain, which is important for receptor kinase activation. In consequence, activation of the receptors can lead to signal transduction through multiple pathways including phospholipase $\mathrm{C} \gamma$ (Mohammadi et al. 1991), phosphatidylinositol 3-kinase (PI3K; Hart et al. 2001), mitogen-activated protein kinases (MAPKs; Hadari et al. 2001), and signal transducers and activators of transcription (STAT; Hart et al. 2000, Deo et al. 2002, Udayakumar et al. 2002). The oncogenic role of STAT3 in various cancers including those of the prostate is well documented (Burke et al. 2001, Klein et al. 2003, Hodge et al. 2005). The activation of STAT3 is associated with either inhibition or promotion of prostate tumour growth (Spiotto \& Chung 2000, Giri et al. 2001). In previous studies, we showed that STAT3 phosphorylation inversely correlates with the expression of suppressor of cytokine signalling-3 (SOCS-3) in prostate cancer cells, suggesting an inactivation of the Janus kinase (JAK)-STAT pathway in the presence of SOCS-3 (Bellezza et al. 2006). The SOCS family consists of eight members, SOCS-1-7 and CIS. All these proteins contain a $\mathrm{N}$-terminal region of variable length, a central $\mathrm{SH} 2$ domain, and a conserved C-terminal region called SOCS box. The complex can recruit E2 ubiquitin transferases (Kamura et al. 2004). Thus, the protein can act as an E3 ubiquitin ligase, and mediates proteasomal degradation of associated proteins. SOCS-3 is induced especially by interleukin-6 (IL-6), a multifunctional cytokine, which plays an important role in chronic inflammation of the prostate (DeMarzo et al. 2003, Wong et al. 2008) and prostate carcinogenesis (Hammacher et al. 2005). IL-6-mediated JAK and STAT3 activation can be directly inhibited through the kinase inhibitory region or through high-affinity binding of SOCS-3 to the IL-6 receptor subunit gp130 (Nicholson et al. 2000).
Thus far, it was shown that SOCS-3 is not only a negative feedback regulator of the IL- 6 receptor, but can also interact with tyrosine kinase receptors, such as insulin-like growth factor receptor 1 (IGFR1; Yadav et al. 2005), epidermal growth factor receptor (Xia et al. 2002) and FGFR (Ben-Zvi et al. 2006). It became evident that SOCS proteins inhibit the action of other peptides, such as IGF (Yadav et al. 2005). We hypothesised that SOCS-3 interferes with the action of FGF-2 in prostate cancer cells.

In this study, we demonstrate for the first time that SOCS-3 is a key regulator of the FGF pathway. SOCS-3 interferes with FGF-2 signalling by influencing the phosphorylation of the MAPK p44 and p42 in DU-145, LNCaP-IL-6 + and LNCaP prostate cancer cells. By modulating SOCS-3 expression levels, we could clearly demonstrate that SOCS-3 has an inhibitory effect on the activation of the MAPK signal transduction. Overexpression of SOCS-3 leads to decreased p44 and p42 activation and in consequence to a diminished cell proliferation and migration. Thus, in the present study, we have shown that SOCS-3 interference with FGF-2 signalling is relevant to prostate cancer progression.

\section{Materials and methods}

\section{Cell culture and chemicals}

LNCaP and DU-145 prostate cancer cells were obtained from American Type Culture Collection (Rockville, MD, USA). The LNCaP subline LNCaPIL-6 + was derived in the presence of IL-6, as described elsewhere (Hobisch et al. 2001). LNCaP cells, stably expressing cmycSOCS-3, were cultured and used as already described in detail in a previous study (Neuwirt et al. 2007). All cell lines were cultured in RPMI 1640 (PAA Laboratories, Pasching, Austria). Media were supplemented with $10 \%$ FCS and $1 \%$ penicillin/streptomycin and glutamine. FGF-2 was a product of Cell Signaling (Danvers, MA, USA). Anisomycin, which was used to induce p38 phosphorylation, was purchased from Sigma.

\section{Short interfering RNA transfection}

The short interfering RNA (siRNA) sequence used for targeting human SOCS-3 was published previously (Komyod et al. 2007) as follows: sense, 5-CCAAGA ACCUGCGCAUCCAdTdT-3; antisense, 5-UGGAU GCGCAGGUUCUUGGdTdT-3 and synthesised by Genxpress (Vienna, Austria). A non-targeting siRNA pool (Cat. no.: D-001810-10-20, Dharmacon (Chicago, IL, USA)) was used as a negative control. 
Transfections with siRNA were performed with Lipofectamine 2000 (Invitrogen) according to the manufacturer's protocol. DU-145 and LNCaP-IL-6+ cells were seeded at a density of $2.5 \times 10^{5}$ /well onto six-well plates. On the next day, the cells were transfected with either $100 \mathrm{nM}$ siRNA against SOCS-3 or control siRNA for a period of 3 days, and harvested and lysed for western blot analysis.

\section{RNA isolation and RT-PCR}

Cells were grown on six-well plates. Subsequently, total RNA was isolated using the RNeasy mini kit (Qiagen) following the manufacturer's protocol. cDNA synthesis was performed using iScript select cDNA synthesis kit (Bio-Rad). Real-time PCR conditions were as follows: one cycle of denaturing at $95^{\circ} \mathrm{C}$ for $10 \mathrm{~min}$ followed by 40 cycles of $95^{\circ} \mathrm{C}$ for $15 \mathrm{~s}$ and $60{ }^{\circ} \mathrm{C}$ for $1 \mathrm{~min}$. All amplifications were performed in triplicates. TATA-box-binding protein (TBP) was chosen as an endogenous expression standard (Savinainen et al. 2002). Primer and probe sequences were as follows: SOCS-3 (forward $5^{\prime}$-TGATCCGCGACAGCTCG-3'; reverse $5^{\prime}$-TCCCAGACTGGGTCTTGACG-3'; TaqMan probe $5^{\prime}$-FAM-CCAGCGCCACTTCTTCACGCTCA-TAMRA-3'), TBP (forward 5'-CACGAACCACGGCACTGATT-3'; reverse 5'-TTTTCTGCTGCCAGTCTGGAC-3'; TaqMan probe 5'-FAM-TCTTCACTCTTGGCTCCTGTGCACA-TAMRA- $3^{\prime}$ ). Each reaction was performed in a $11-\mu \mathrm{l}$ volume containing $50 \mathrm{ng} \mathrm{cDNA}$ and $5.5 \mu \mathrm{l}$ of $2 \times$ ABI Mastermix (Applied Biosystems, Foster City, CA, USA). The primers were added to a final concentration of $900 \mathrm{nmol} / \mathrm{l}$, and the final probe concentration was $150 \mathrm{nmol} / \mathrm{l}$. PCR products were measured using the ABI Prism 7500 Fast RT-PCR System (Applied Biosystems). $C_{\mathrm{t}}$ values of SOCS-3 and TBP as assessed by ABI Sequence Detection Software (version 1.3) were used to calculate the $\Delta C_{\mathrm{t}}$ using Microsoft Excel. Values obtained in control cells were defined as $100 \%$, and those from treated cells were expressed as a percentage of control.

\section{Western blot}

Cells were harvested, washed with PBS, and lysed in EORTC buffer. The total protein was quantified using the Bradford method (Bradford 1976). Fifty micrograms of protein per lane were then resolved using a 4-12\% Bis-Tris gel (Invitrogen), and transferred onto a nitrocellulose membrane (Invitrogen). Western blot was carried out as described elsewhere (Puhr et al. 2009). The following antibodies were used for western blots: SOCS-3 (1:1000; Acris Antibodies,
Hiddenhausen, Germany), GAPDH (1:100 000; Millipore, Vienna, Austria), phospho-STAT3 (1:200; Upstate Cell Signaling Technology, Beverly, MA, USA), STAT3 (1:1000; Santa Cruz Biotechnology, Santa Cruz, CA, USA), phospho-STAT1 (1:500; Santa Cruz), STAT1 (1:1000; Santa Cruz), Akt (1:1000; Cell Signaling), pAkt (1:500; Cell Signaling), pp44/42 (1:500; Cell Signaling), p44 (1:1000; Santa Cruz), p42 (1:1000; Santa Cruz), pp38 (1:250; New England Biolabs, Ipswich, MA, USA) and p38 (1:500, New England Biolabs).

\section{$\left[{ }^{3} \mathrm{H}\right]$ thymidine incorporation assay}

DU-145 and LNCaP-IL-6 + cells were seeded at a density of $3.5 \times 10^{3} /$ well, and cmycSOCS-3 stably transfected LNCaP cells were seeded at a density of $1.5 \times 10^{4} /$ well in triplicates onto 96 -well plates. On the following day, full medium was changed to starving medium and FGF-2 for DU-145 and LNCaP-IL-6+ cells, or FGF-2 and doxycycline for LNCaP cells. The cells were incubated for 5 days. At day 3, the medium was changed, and FGF-2 and doxycycline were again added to the cells. To each well, $25 \mu \mathrm{l}$ of $\left[{ }^{3} \mathrm{H}\right]$ thymidine $(1 \mu \mathrm{Ci} /$ well $)$ were added, and DNA was harvested on day 5 on 96-well filter plates (UniFilter, Perkin Elmer, Boston, MA, USA) after a $24 \mathrm{~h}$ incubation. Fifty microlitres of scintillation fluid were added, and radioactivity was quantified using Hidex Chameleon V liquid scintillation counter (HVD Life Sciences, Vienna, Austria).

\section{Wound-filling assay}

DU-145 and LNCaP-IL-6 + cells were seeded at a density of $3.5 \times 10^{5} /$ well in six-well plates and transiently transfected with a doxycycline-inducible cmycSOCS-3 plasmid. The transfection was performed with FuGENE 6 (Roche Diagnostics) according to the manufacturer's protocol. Identical scratches were made in parallel wells $24 \mathrm{~h}$ after the transfection with a 1000- $\mu$ lip, and doxycycline and FGF-2 were added respectively. Pictures were taken at 0,24 and $48 \mathrm{~h}$.

\section{Statistical analysis}

For each treatment group, statistical significance was determined by Mann-Whitney $U$ test. $P$ values $<0.05$ were defined as statistically significant and encoded in figures $(* P<0.05$ and $* * P<0.01)$. Statistical analyses were performed using SPSS 12.0 software (SPSS, Chicago, IL, USA). 


\section{Results}

\section{Activation of the $\mathrm{p} 44 / \mathrm{p} 42$ signalling pathway by FGF-2 in prostate cancer cells}

Phosphorylation of ligand-bound FGFRs may lead to the activation of multiple downstream signal transduction pathways, such as those of STAT, MAPK and Akt. Because FGF-2 signalling has not been characterised in prostate cancer so far, we analysed the activation of different signalling pathways after FGF-2 stimulation in prostate cancer cells. For this purpose, we treated DU-145 and LNCaP-IL-6 + cells that represent advanced carcinoma of the prostate with increasing concentrations of FGF-2 (1-100 ng/ml) for $15 \mathrm{~min}$, and verified protein phosphorylation by western blot afterwards. LNCaP cells, treated with $10 \mathrm{ng} / \mathrm{ml} \mathrm{IL}-6$ for $15 \mathrm{~min}$, were used as a positive control. In the presence of FGF-2, neither STAT3, STAT1, p38 MAPK, nor Akt could be phosphorylated, even with the highest growth factor concentration in DU-145 cells (Fig. 1a, Supplementary Figure 1, see section on supplementary data given at the end of this article). In LNCaP-IL-6 + cells, no STAT3 and Akt phosphorylation was detectable, whereas a minor STAT1 phosphorylation (Fig. 1b) could be observed. However, there was no difference in phosphorylation intensity between control and FGF-2-treated cells.

We also investigated a possible activation of the p44/p42 MAPK pathway. Therefore, we measured p44/p42 phosphorylation in both cell lines after 15 and 45 min of FGF-2 treatment. Western blot data showed a significant dose-dependent increase of $\mathrm{p} 44 / \mathrm{p} 42$ phosphorylation in DU-145 and LNCaP-IL-6 + cells at both time points (Fig. 2).

\section{FGF-2 differentially regulates SOCS-3 in two prostate cancer cell lines}

In several cellular models, IL-6 was identified as a classical inducer of SOCS-3, which in turn limits the activation of the JAK-STAT pathway. To study the possible effects of FGF-2 on SOCS-3 expression, SOCS-3 protein levels were measured in both cell lines. We observed a moderate increase of SOCS-3 expression by FGF-2 in DU-145 cells (Fig. 2a) within 15 min. In LNCaP-IL-6 + cells, we did not observe changes in SOCS-3 expression after treatment with $1 \mathrm{ng} / \mathrm{ml}$ FGF-2. However, a decrease of SOCS-3 expression with $100 \mathrm{ng} / \mathrm{ml}$ of FGF-2 was noted (Fig. 2b). SOCS-3 mRNA levels were not altered after FGF-2 short-time treatment (data not shown).

After long-term treatments with FGF-2 (up to 5 days), we could confirm these findings (Fig. 3). (a)
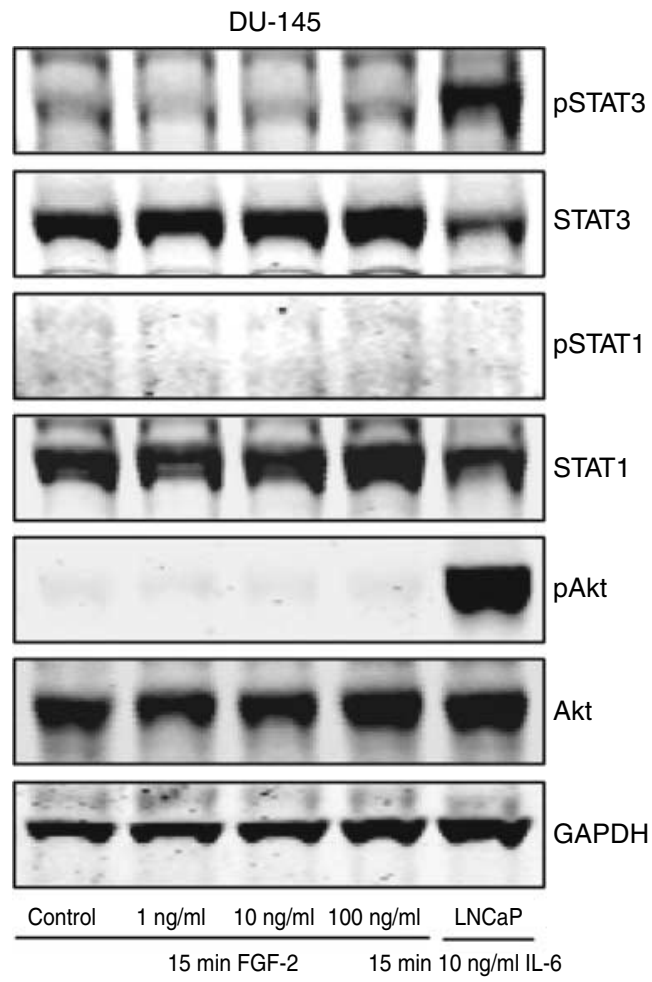

(b)
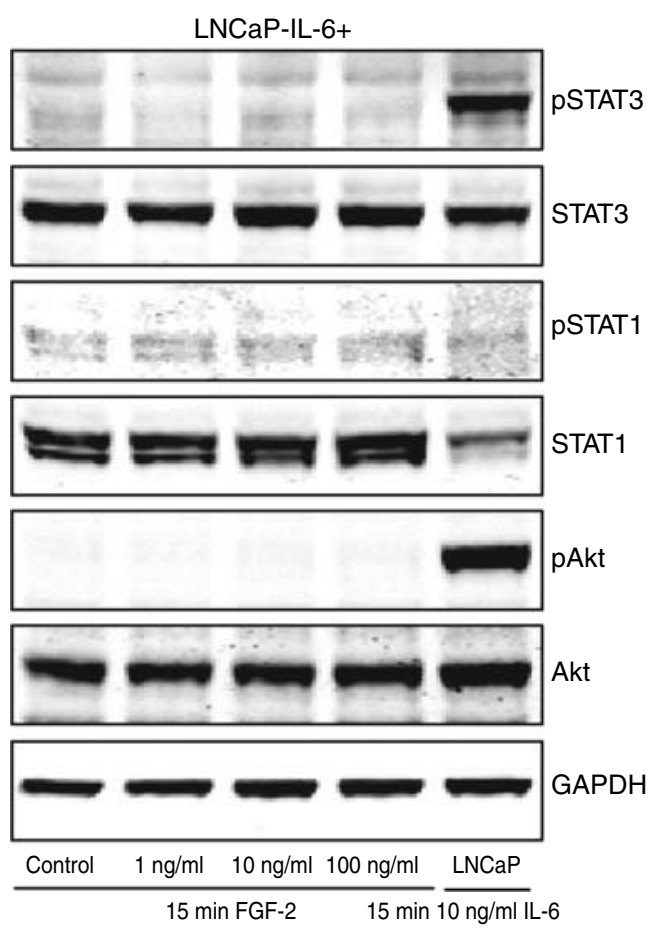

Figure 1 FGF-2 stimulation does not activate STAT3, STAT1 or Akt in prostate cancer cells. Western blot analysis for STAT3, STAT1, and Akt signal transduction pathway activation after treatment with increasing concentrations of FGF-2 for $15 \mathrm{~min}$ in DU-145 (a) and LNCaP-IL-6 + cells (b). LNCaP cells, treated with $10 \mathrm{ng} / \mathrm{ml} \mathrm{IL-} 6$ for $15 \mathrm{~min}$, were used as a control for the activation of the STAT3 and Akt pathways. 

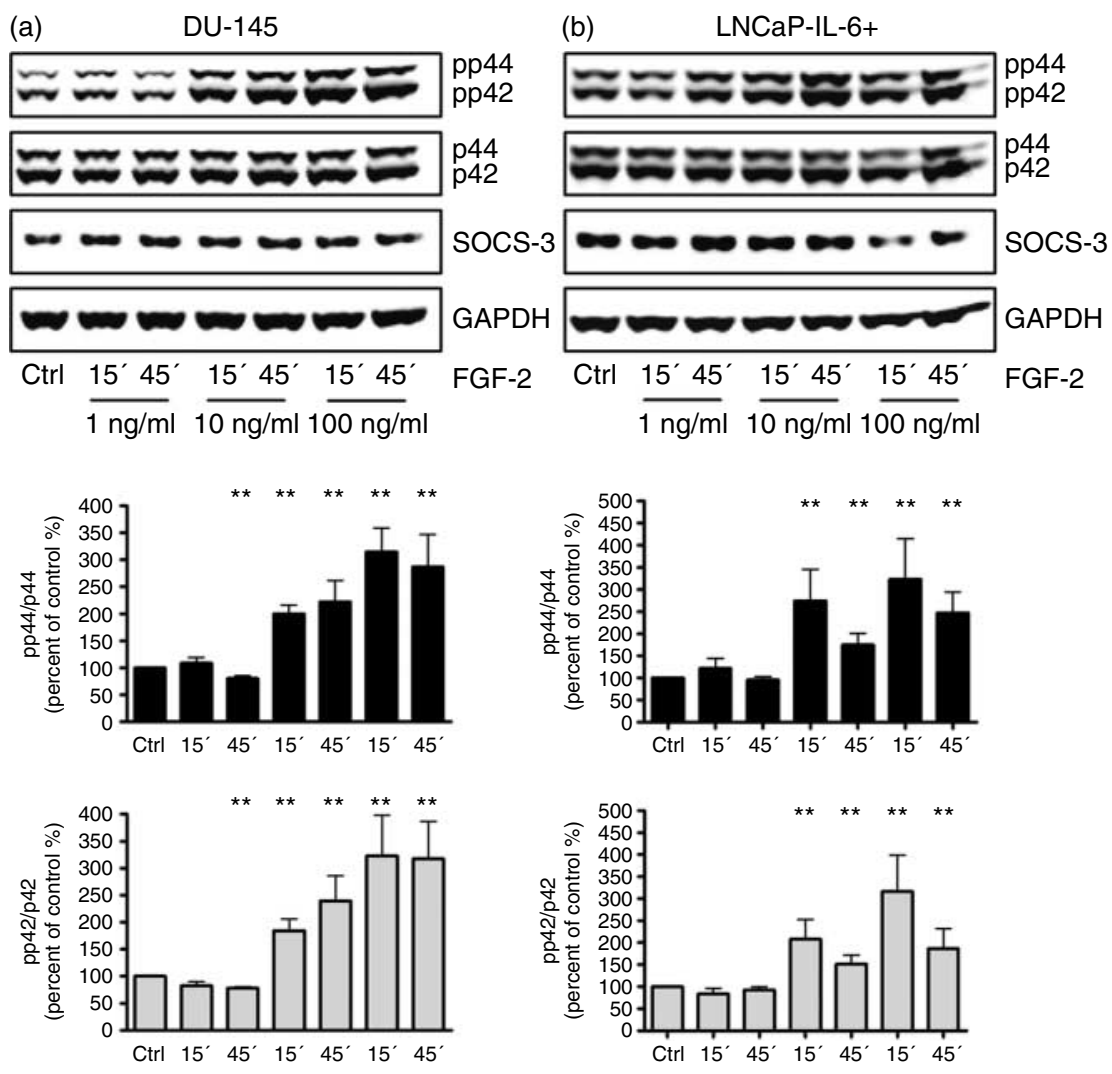

Figure 2 Specific activation of the MAPK pathway and regulation of SOCS-3 after FGF-2 stimulation. Western blot analysis for MAPK activation and SOCS-3 expression in DU-145 (a) and LNCaP-IL-6 + cells (b). Treatment with FGF-2 for 15 and 45 min leads to a dose-dependent phosphorylation of p44 and p42, key proteins of the MAPK pathway (mean values + S.E.M. from at least three independent experiments). ${ }^{\star *}, P<0.01$.

No significant change of SOCS-3 mRNA levels could be observed in both cell lines after 5 days (Fig. 3a and c). At protein level, we observed a significant increase of SOCS-3 expression with $1 \mathrm{ng} / \mathrm{ml}$ of FGF-2 and a dose-dependent decline with increasing concentrations of FGF-2 in DU-145 cells (Fig. 3b). In LNCaP-IL-6+ cells, similar to the short-time treatment, a significant decrease of SOCS-3 expression could be detected with 10 and $100 \mathrm{ng} / \mathrm{ml} \mathrm{FGF-2} \mathrm{(Fig.} \mathrm{3d).}$

\section{FGF-2-induced p44/p42 phosphorylation is required for prostate cancer cells' proliferation}

In order to investigate the consequences of increased p44/p42 phosphorylation, DU-145 and LNCaP-IL-6+ cells were incubated with 10 and $100 \mathrm{ng} / \mathrm{ml}$ FGF-2 for 5 days (Fig. $4 a$ and b). Cellular proliferation was measured using $\left[{ }^{3} \mathrm{H}\right]$ thymidine incorporation. To clarify whether altered cellular proliferation is a specific consequence of $\mathrm{p} 44 / \mathrm{p} 42$ activation, we incubated both cell lines in the presence of FGF-2 and the specific MAPK inhibitor PD98059.
We observed a significant increase in proliferation caused by 10 and $100 \mathrm{ng} / \mathrm{ml}$ FGF-2 in both cell lines after 5 days, whereas in the presence of $25 \mu \mathrm{M}$ PD98059 no significant alteration could be detected. Concentrations higher than $25 \mu \mathrm{M}$ of PD98059 inhibited the proliferation of both FGF-treated and -untreated prostate cancer cell lines (data not shown), since it is known that DU-145 and LNCaP-IL-6 + cells show up-regulated p44/p42 activity (Putz et al. 1999, Steiner et al. 2003). The data presented in Fig. 4 illustrate that $\mathrm{p} 44 / \mathrm{p} 42$ phosphorylation is required for proliferation of DU-145 and LNCaP-IL-6 + cells.

\section{SOCS-3 downregulation results in increased p44/p42 phosphorylation}

To determine whether SOCS-3 expression has an impact on $\mathrm{p} 44 / \mathrm{p} 42$ phosphorylation, we transfected DU-145 and LNCaP-IL-6 + cells with $100 \mathrm{nM}$ control siRNA or siRNA against SOCS-3 as indicated and measured SOCS-3 protein expression levels and p44/p42 phosphorylation after 3 days (Fig. 5a and c). 

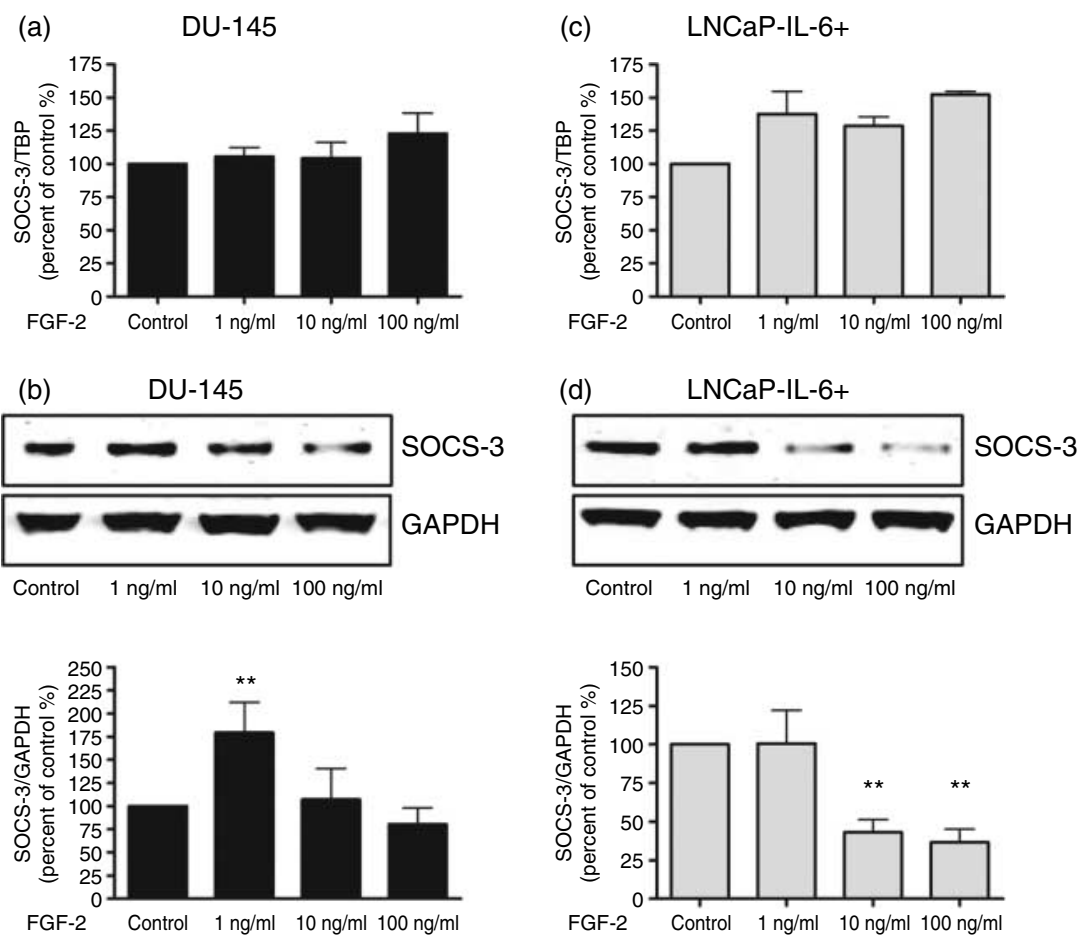

Figure 3 SOCS-3 expression is regulated at protein but not at mRNA level after FGF-2 treatment. DU-145 (a and b) and LNCaP-IL-6 + cells (c and d) were treated two times with 1,10 and $100 \mathrm{ng} / \mathrm{ml} \mathrm{FGF-2} \mathrm{during} \mathrm{a} \mathrm{period} \mathrm{of} 5$ days. The cells were then harvested, and qRT-PCR and western blot were performed respectively. The results are expressed in relation to values measured in untreated cells and represent mean values + S.E.M. from at least three independent experiments. ${ }^{* *}, P<0.01$.

We observed a significant $50-55 \%$ decrease of SOCS-3 protein in both cell lines. A larger decrease in SOCS-3 expression yields massive cell death which could compromise proliferation and migration experiments (Puhr et al. 2009). At the same time, a 2.5 -fold increase in $\mathrm{p} 44 / \mathrm{p} 42$ phosphorylation could be measured in DU-145 cells. In LNCaP-IL-6 + cells, an increase in phosphorylation could also be detected. Nevertheless, it was not significant compared with the negative control.

Next, we incubated both cell lines with $1 \mathrm{ng} / \mathrm{ml}$ FGF-2 for 15 and 45 min after siRNA treatment, and measured p44/p42 phosphorylation again. A significant 3.5-fold increase in $\mathrm{p} 44 / \mathrm{p} 42$ phosphorylation was observed compared to the treated negative control, when SOCS-3 protein expression was significantly decreased in DU-145 cells (Fig. 5b). In the LNCaP-IL-6+ cell line, a similar twofold increase in p44/p42 phosphorylation was measured (Fig. 5d).

\section{SOCS-3 overexpression yields decreased p44/p42 phosphorylation}

To examine whether SOCS-3 regulation of p44/p42 phosphorylation is a general phenomenon, we stably transfected SOCS-3-negative $\mathrm{LNCaP}$ cells with a doxycycline-inducible cmycSOCS-3 plasmid (Neuwirt et al. 2007). After induction of cmycSOCS-3 by doxycycline, the cells were incubated with $10 \mathrm{ng} / \mathrm{ml}$ IL-6 (Fig. 6a) or FGF-2 (Fig. 6b) for 15 and 45 min, and $\mathrm{p} 44 / \mathrm{p} 42$ phosphorylation was measured afterwards. In the presence of increased SOCS-3 protein levels, a significant decrease in $\mathrm{p} 44 / \mathrm{p} 42$ phosphorylation could be detected, compared to the doxycyclineuntreated control after IL-6 or FGF-2 stimulation for both time points.

\section{Overexpression of SOCS-3 diminished FGF-2-induced proliferation and migration}

In our previous studies, it was demonstrated that SOCS-3 may exhibit different effects on proliferation and apoptosis in androgen-sensitive and -insensitive cells. Decreased p44/p42 phosphorylation, a consequence of SOCS-3 overexpression, has a significant impact on cell proliferation (Fig. 7). Proliferation of stably transfected LNCaP cells was measured after 5 days of stimulation by FGF-2 in the absence or in the presence of doxycycline, as indicated, using $\left[{ }^{3} \mathrm{H}\right]$ thymidine incorporation assay. When SOCS-3 was not present in LNCaP cells, a dose-dependent 
(a)

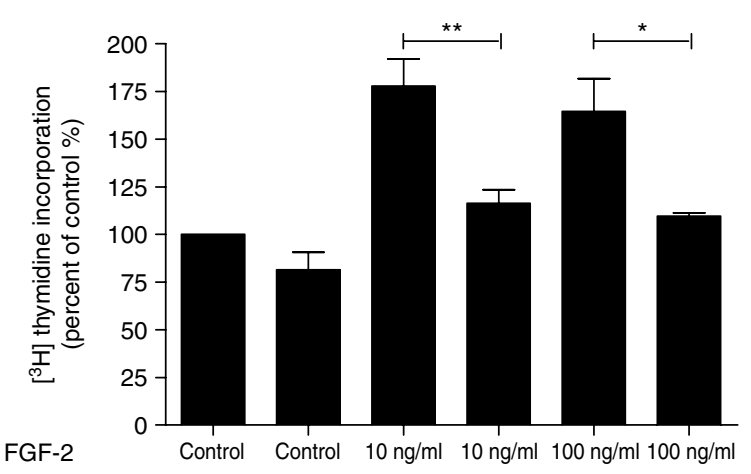

PD98059 $25 \mu \mathrm{M}-$

DMSO
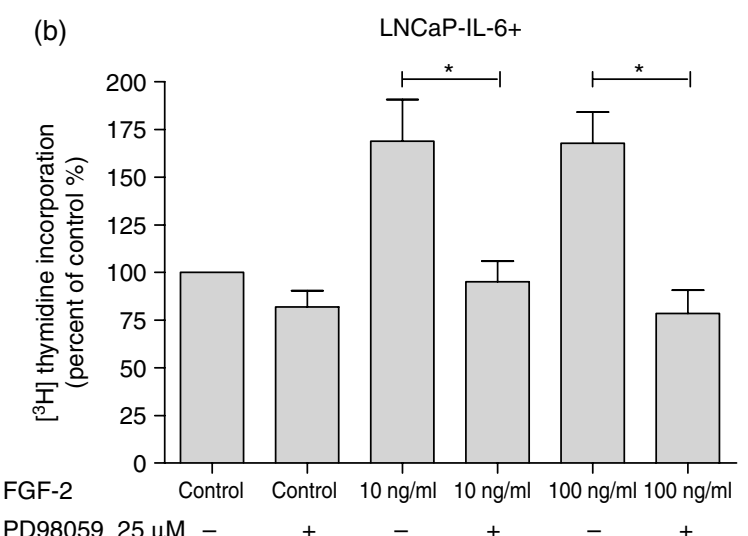

DMSO

Figure 4 Increased p44/p42 phosphorylation is crucial for prostate cancer cell proliferation. Regulation of cellular proliferation in DU-145 (a) and LNCaP-IL-6 + (b) cells. Consecutive treatment with FGF-2 during a period of 5 days causes an increase of proliferation in both cell lines. This effect could be reversed in the presence of the MAPK inhibitor PD98059. Cellular proliferation was assessed by the measurement of $\left[{ }^{3} \mathrm{H}\right]$ thymidine incorporation (mean values + S.E.M. from at least three independent experiments). The percentage of untreated cells was set at $100 \%$. ${ }^{*}, P<0.05$; **, $P<0.01$.

significant increase in proliferation could be measured with 10 and $100 \mathrm{ng} / \mathrm{ml} \mathrm{FGF-2} \mathrm{(Fig.} \mathrm{7a).} \mathrm{On} \mathrm{the}$ contrary, in the presence of SOCS-3, no increase in proliferation could be observed (Fig. 7b).

To get a better insight whether increased SOCS-3 expression has also an effect on migration of DU-145 and LNCaP-IL-6 + cells, we performed a woundfilling assay 3 days after transient transfection with the doxycycline-inducible cmycSOCS-3 plasmid (Fig. 8). Twenty-four hours after adding $10 \mathrm{ng} / \mathrm{ml}$ FGF-2, an obvious difference between the treatment groups could be observed in both cell lines. Thus, induction of SOCS-3 by doxycycline resulted in a reduced migration of prostate cancer cells. After $48 \mathrm{~h}$, this difference between the cells treated with FGF-2 and those treated with FGF-2 and doxycycline was even more evident.

\section{Discussion}

\section{FGF-2 endogenous inhibitors are differently expressed in prostate cancer}

To the best of our knowledge, prior to this study, there was no published evidence that SOCS-3 interacts with elements of FGF pathways in cancer or represses MAPK activation. To get more insight into the regulation of FGF-2-mediated cellular events by SOCS-3, we investigated a possible interference of SOCS-3 with FGF-2 signal transduction and examined its biological consequences in prostate cancer in vitro. For this purpose, we used DU-145, LNCaP and LNCaPIL-6 + cells, which are established models for advanced prostate cancer. FGFs and their receptors influence different stages of prostate carcinogenesis (Leung et al. 1996, Dorkin et al. 1999). Overexpression of multiple FGFs, especially of FGF-2, and an altered expression of FGFRs have been reported in prostate cancer (Giri et al. 1999). Indeed, FGF-2 has mitogenic and angiogenic characteristics, and can promote tumour progression (Powers et al. 2000, Polnaszek et al. 2003). Therefore, it is important to identify endogenous inhibitors of FGF signalling in carcinoma of the prostate.

FGF-2 overexpression and, in consequence, altered signal transduction are also linked to a significant decrease in some of the regulators of the FGF pathway. Kwabi-Addo et al. (2004) could show that a member of the Sprouty family, Sprouty 1, an important negative feedback inhibitor of FGF-2, is significantly decreased in prostate cancer. Recently, it was reported that Sprouty 4, another member of this family which is involved in the regulation of cellular migration, is silenced through hypermethylation (Wang et al. 2006). Dipeptidyl peptidase, a serine protease which regulates the activities of several mitogens, is another example for an endogenous FGF-2 inhibitor, whose expression is decreased in prostate cancer (Wesley et al. 2005). We identified in the present study SOCS-3 as a novel inhibitor of FGF-2 signalling. In contrast to the Sprouty proteins or dipeptidyl peptidase, SOCS-3 is expressed in prostate cancer cells and tissues obtained from patients with prostate intraepithelial neoplasia or cancer including those who failed endocrine therapy (Puhr et al. 2009). For SOCS-3 inhibitory function of FGF-2 function in vivo, the expression of growth factor inhibitors belonging to the Sprouty family or dipeptidyl peptidase may be required. 
(a)

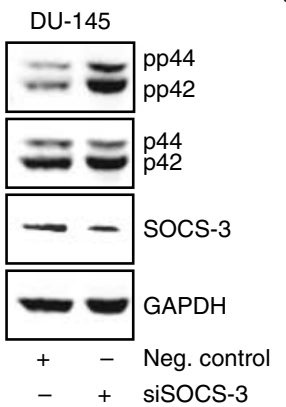

(b)

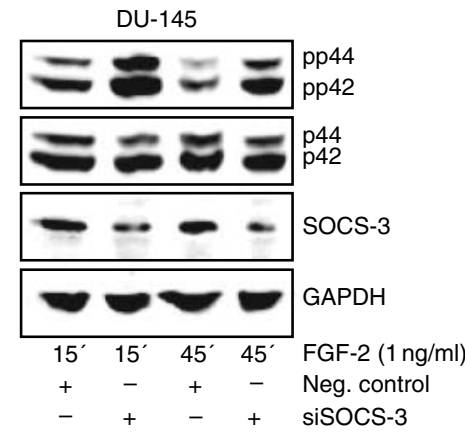

(c)

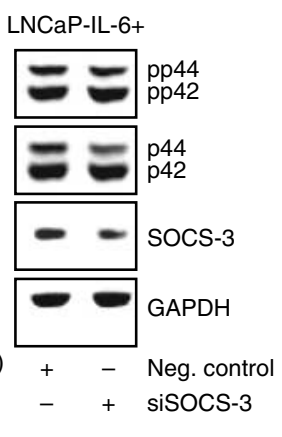

(d)

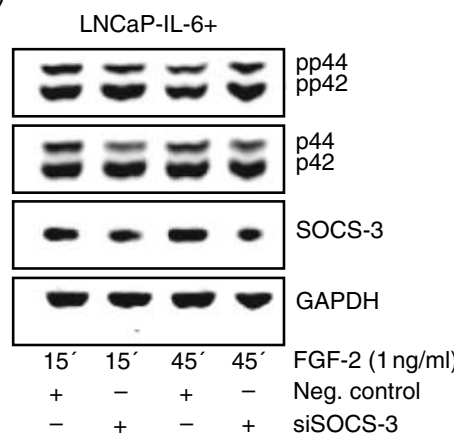

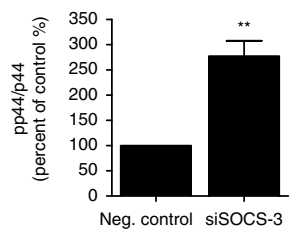
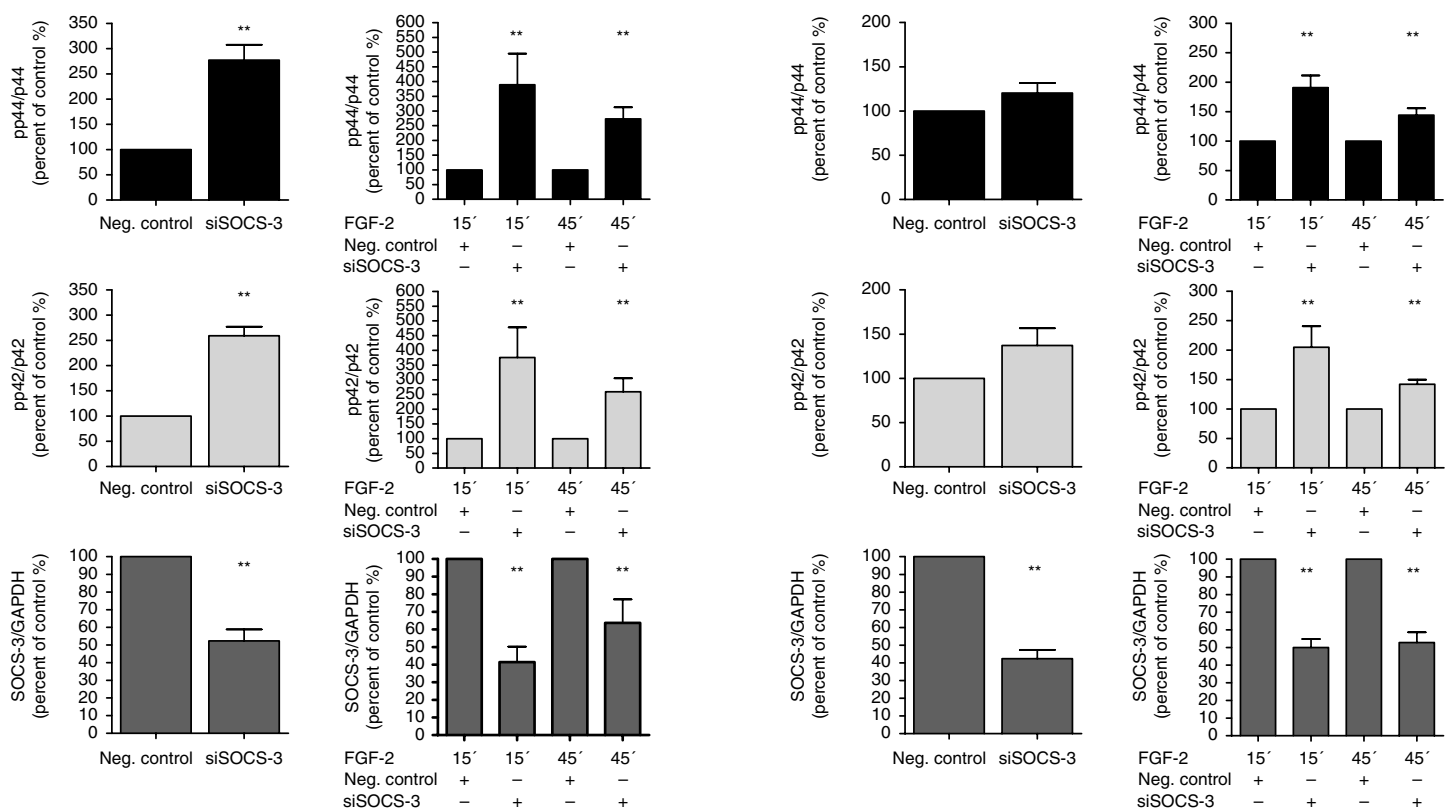

\section{FGF-2} sisocs-3

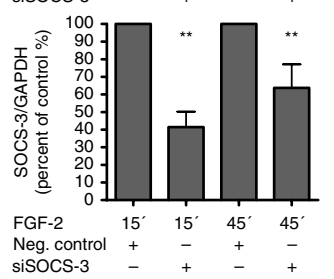

sisOCS-3

Figure 5 Measurement of p44/p42 phosphorylation after SOCS-3 downregulation and FGF-2 stimulation. Western blot analysis for basal p44 and p42 phosphorylation in DU-145 (a) and LNCaP-IL-6 + (c) cells after SOCS-3 downregulation for 3 days. Cells were treated with specific SOCS-3 or negative control siRNA. Treatment with $1 \mathrm{ng} / \mathrm{ml} \mathrm{FGF-2} \mathrm{for} 15$ and $45 \mathrm{~min}$ in DU-145 (b) and LNCaP-IL-6 + cells (d) resulted in an increased p44/42 phosphorylation. The results are expressed in relation to values measured in cells treated with negative control siRNA and represent mean values + S.E.M. from at least three independent experiments. ${ }^{\star *}, P<0.01$.

\section{SOCS-3 is a regulator of receptor tyrosine kinases}

There is accumulated evidence that the inhibitory role of SOCS-3 is not limited to IL-6 signalling. Furthermore, SOCS-3 can bind to tyrosine kinase receptors and interfere with their signal transduction. Ben-Zvi et al. (2006) could show that SOCS-3 and SOCS-1 bind to FGFR3 in HEK-293T cells. In those cells, SOCS-1 overexpression elevated MAPK phosphorylation, in contrast to the effect of SOCS-3 in prostate cancer, and repressed STAT1 phosphorylation. An interaction between the IGF1 pathway and SOCS-3 has been analysed. SOCS-3 is induced in response to IGF1 in neurons, and antagonises its effect on survival through binding to the IGFR1 (Yadav et al. 2005). IGF1 also upregulates SOCS-3 during differentiation of myoblasts, thus inducing transcriptional activation of the $\alpha$-actin promoter (Spangenburg 2005).

In prostate cancer cells, FGF-2 acts through MAPK rather than through the JAK/STAT pathway. SOCS proteins were originally identified as main inhibitors of the STAT pathway. This effect of SOCS-3 on growth factor signalling is not limited to a single cell line. It was observed in DU-145 and LNCaP-IL-6 + cells, which express endogenous SOCS-3, and in LNCaP clones, in which SOCS-3 expression was induced after doxycycline treatment. On the basis of these results and our previous work, we conclude that SOCS-3 in human 
(a)
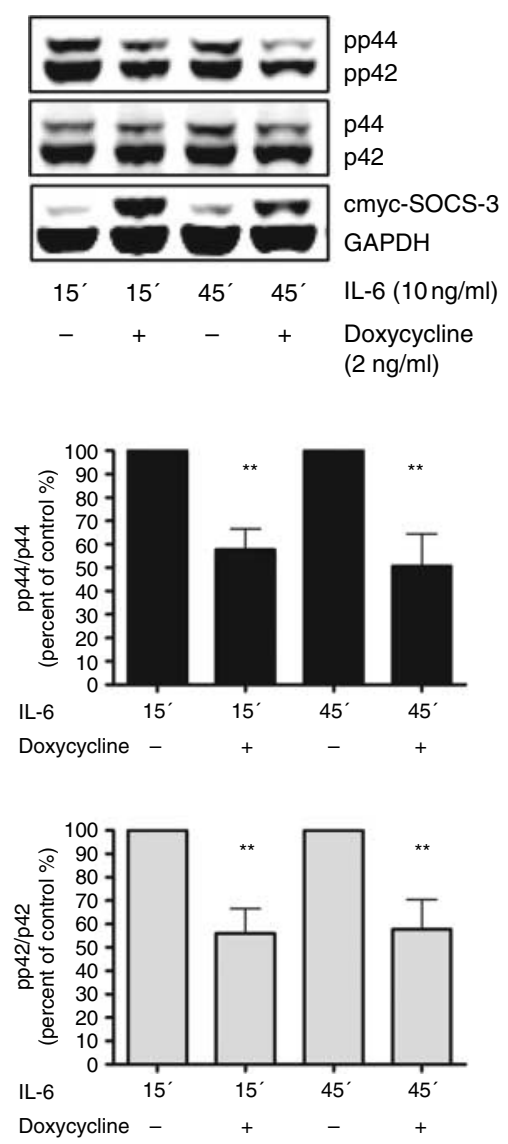

(b)
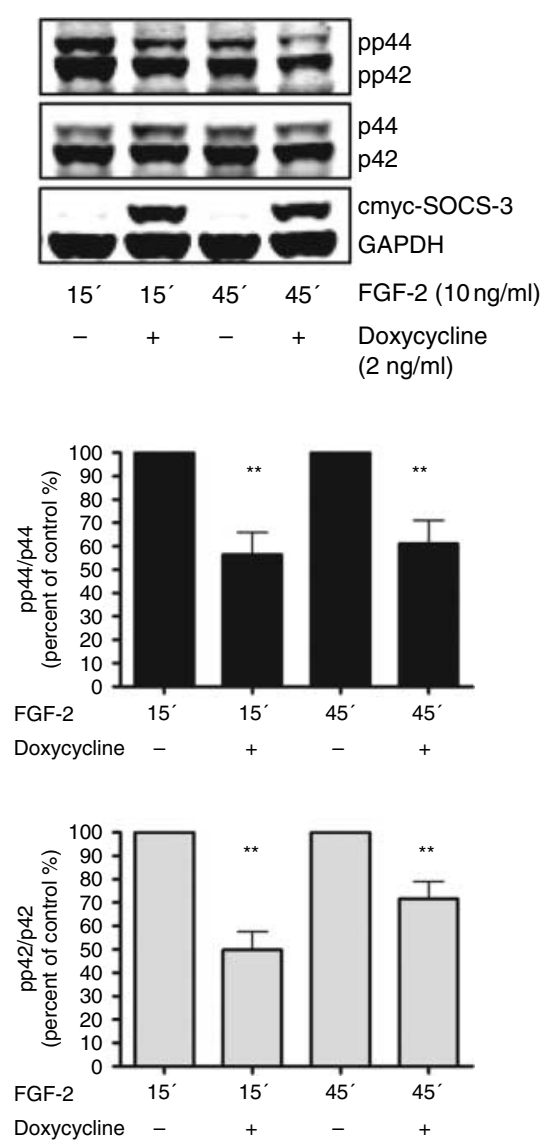

Figure 6 Overexpression of SOCS-3 results in a decreased p44/p42 phosphorylation. Western blot analysis for p44/p42 phosphorylation in SOCS-3-overexpressing LNCaP cells. The presence of SOCS-3 leads to a significantly decreased p44/p42 phosphorylation after 15 and 45 min after IL-6 (a) and FGF-2 (b) treatment in cmycSOCS-3-transfected LNCaP cells. ${ }^{\star \star}, P<0.01$.

prostate cancer has multiple functions. Its expression in prostate cells can be induced by IL-6, cAMP and androgens (Bellezza et al. 2006, Neuwirt et al. 2007). Importantly, the implications of SOCS-3 induction by each of these compounds may be contrasting. CAMPinduced SOCS-3 expression yields increased proliferation and reduced cell death (Bellezza et al. 2006). In androgen-sensitive cells, SOCS-3 antagonises hormonal effect on proliferation by interfering with key regulators of cell cycle progression (Neuwirt et al. 2007). Further studies to assess the implications of inhibition of SOCS-3 expression in prostate cancer in vivo may be therefore justified.

\section{FGF-2 activation of intracellular signalling is cell type specific}

The treatment of DU-145 and LNCaP-IL-6 + cells with increasing concentrations of FGF-2 did not result in phosphorylation of STAT3 and STAT1. These findings were consistent with our previous results, which showed that STAT3 and STAT1 phosphorylation in prostate cancer inversely correlates with SOCS-3 expression in vitro (Bellezza et al. 2006, Puhr et al. 2009). In SOCS-3-positive cell lines, STAT3 cannot be phosphorylated. Treatment of prostate cancer cells with SOCS-3 siRNA led to increased phosphorylation of STAT factors. The results showing a lack of effect of FGF-2 on STAT phosphorylation are in line with those of Ishikawa et al. (2005). They could not detect phosphorylation of STAT3 and STAT1 after FGF-2 stimulation in a myeloma cell line. On the other hand, Deo et al. (2002) reported STAT3 phosphorylation after FGF-2 stimulation in human umbilical vein endothelial cells. Thus, the phosphorylation of STATs after FGF-2 stimulation depends on cellular context. As we were not able to detect the activation of the PI3K pathway after FGF-2 treatment, we focused on MAPK in the present study. Indeed, the treatment with increasing concentrations of FGF-2 


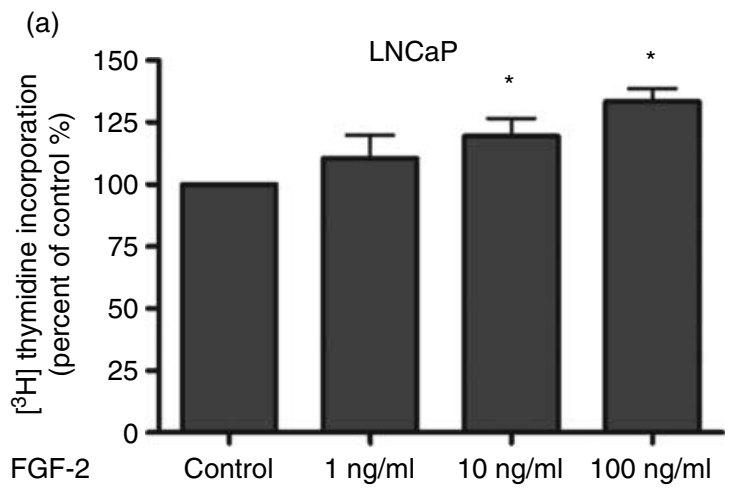

Doxycycline -

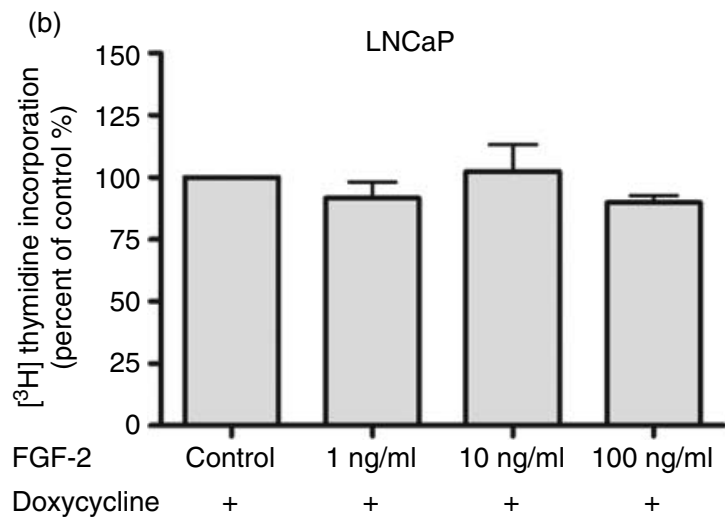

Figure 7 Cellular proliferation is decreased in the presence of SOCS-3. Regulation of cellular proliferation in cmycSOCS-3transfected LNCaP cells in the presence or in the absence of doxycycline. Treatment with 10 and $100 \mathrm{ng} / \mathrm{ml} \mathrm{FGF-2}$ during a period of 5 days causes a significant increase of proliferation. This effect could be reversed in the presence of $2 \mu \mathrm{g} / \mathrm{ml}$ doxycycline. Cellular proliferation was assessed by the measurement of $\left[{ }^{3} \mathrm{H}\right]$ thymidine incorporation (mean values + S.E.M. from at least three independent experiments). The percentage of untreated cells was set at $100 \%$. ${ }^{*}, P<0.05$.

resulted in a dose-dependent phosphorylation of the MAPK p44 and p42. These data are again in accordance with those of Ishikawa et al. (2005) as well as with those of two other groups who showed that the FGF-2 effect is mediated through this pathway in prostate cancer cellular models (Wesley et al. 2005, Hatziapostolou et al. 2006).

\section{SOCS-3 inhibition of p44/p42 MAPK antagonises FGF-2-induced proliferation and migration}

MAPKs have an important role in cellular proliferation, and its phosphorylation is increased in a number of prostate cancer patient cases (Gioeli et al. 1999). To determine whether FGF-2-increased activation of p44 and p42 has an effect on proliferation of DU-145 and LNCaP-IL-6 + cells, they were treated with FGF-2 in the presence or in the absence of the specific MAPK inhibitor PD98059. Our results confirm that increased p44/p42 phosphorylation is required for the FGF-2induced cellular proliferation in prostate cancer. These findings are supported by those of Giri et al. (1999) who showed an increased proliferation of primary prostate epithelial cells after FGF-2 stimulation. Recombinant FGF-2 also stimulated DNA synthesis in DU-145 prostate cancer cells in a previous study. However, the relative effect was lower than that observed in $\mathrm{LNCaP}$ cells which do not produce endogenous FGF-2 (Nakamoto et al. 1992). It should be noted that in prostate cancer cell lines used in the present study, FGFs may exhibit autocrine activity. LNCaP-IL-6 + cells, in contrast to the parental cells, upregulate IL-6 and SOCS-3 (Hobisch et al. 2001, Bellezza et al. 2006). This observation may provide an explanation why addition of exogenous FGF-2 does not elevate SOCS-3 protein expression in the LNCaP-IL-6 + subline.

Importantly, we show that SOCS-3 interference with the p44/p42 MAPK pathway has consequences on proliferation and migration of prostate cancer cells. In LNCaP cells, overexpression of SOCS-3 inhibits FGF-2-induced proliferation. DU-145 and LNCaP-IL-6+ cells show a decreased migrative potential in the presence of elevated SOCS-3 protein levels. We could thus extend the results of a previous work, in which it was revealed that FGF-2 increases the expression and secretion of heparin affin regulatory peptide/ pleiotrophin, cellular proliferation and migration (Hatziapostolou et al. 2006). One could hypothesise that expression of FGF-2 targets such as cyclin E, retinoblastoma or matrix metalloproteinases is affected through the effect of SOCS-3 on p44/p42 MAPK phosphorylation (Muddasani et al. 2007, Takeuchi et al. 2007). We demonstrate for the first time that SOCS-3 may interfere with oncogenic events caused by the $\mathrm{p} 44 / \mathrm{p} 42$ MAPK pathway in cancer. Our findings extend previous knowledge since SOCS proteins were identified as classic inhibitors of the JAK/STAT signal transduction. It remains to be determined which elements of the FGF signalling pathway, such as receptors, interact with SOCS-3. Possible binding partners of SOCS-3 could be members of the MAPK family or the FGFR. FGFR1 is considered to be the most important receptor of the FGFR family for FGF-2 signalling and a known oncoprotein in prostate cancer (Freeman et al. 2003). However, we could not detect an interaction between SOCS-3 and FGFR1 in DU-145 or LNCaP-IL-6 + cells (data not shown). FGFR2, FGFR3, and FGFR4 are also involved in transduction of FGF-2 signalling in malignancies. However, in 

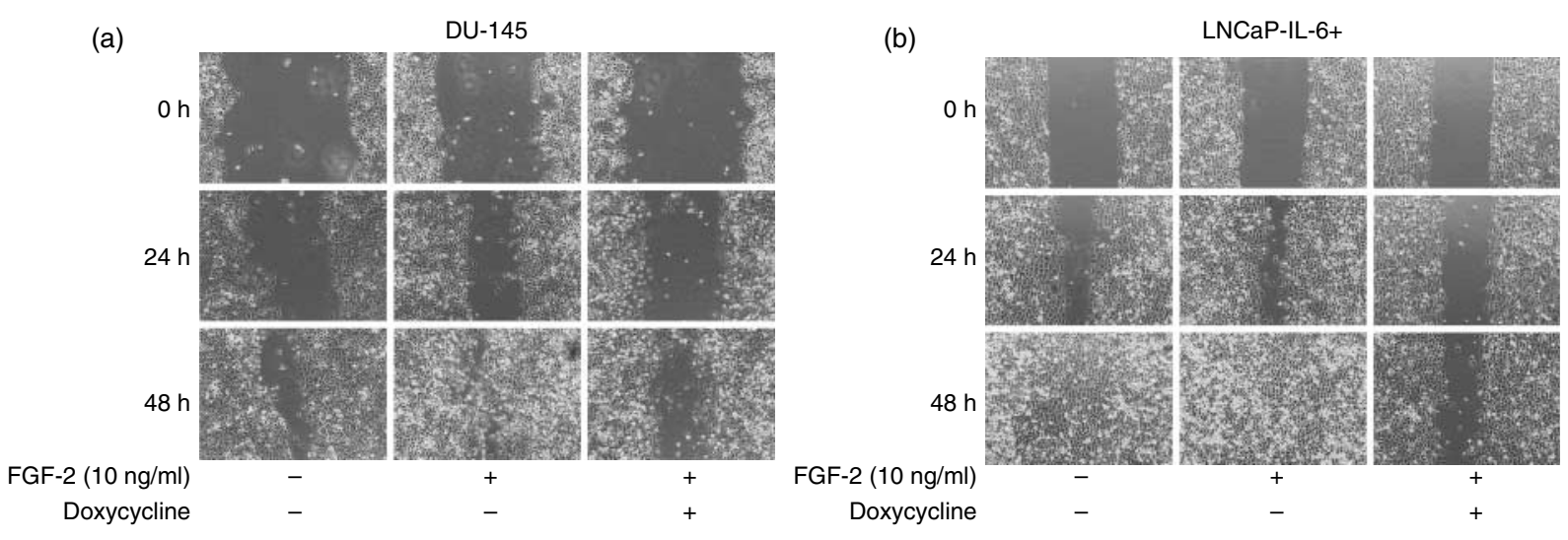

Figure 8 SOCS-3 overexpression neutralises the migratory effect of FGF-2 in a wound-filling assay. SOCS-3 expression was induced with $2 \mu \mathrm{g} / \mathrm{ml}$ doxycycline as indicated. Identical scratches were made in parallel wells using a $1000-\mu \mathrm{l}$ pipette tip $48 \mathrm{~h}$ after transfection. Pictures $(40 \times)$ were taken at 0,24 , and $48 \mathrm{~h}$. The strongest differences between the FGF-2 treatment and the FGF-2+ doxycycline treatment were observed at $48 \mathrm{~h}$ for DU-145 cells (a) and LNCaP-IL-6 + cells (b).

contrast to FGFR1 which is oncogenic, re-expression of FGFR2 in human prostate cancer cells led to the inhibition of growth and tumorigenicity (Yasumoto et al. 2004, Acevedo et al. 2007). The role of FGFR3 and FGFR4 in human prostate cancer is at present less clear, and the implications of receptor mutations should be further investigated (Wang et al. 2004, Hernandez et al. 2009). We hypothesise that the action of SOCS-3 on the FGF-2 signalling pathway is more complex than its interference with IGF1 signalling. In the latter case, it was documented that SOCS-3 interacts with the IGFR1 (Dey et al. 2000).

Two different approaches were used to examine the regulation of MAPK by SOCS-3 in prostate cancer: i) specific siRNA against SOCS-3 and ii) doxycyclineregulated SOCS-3 expression to manipulate SOCS-3 protein expression in prostate cancer cell lines. Downregulation of SOCS-3 resulted in a significant increase of basal p44/p42 phosphorylation in DU-145 cells but not in LNCaP-IL-6 + cells. The basal p44/p42 phosphorylation in LNCaP-IL-6 + cells increased as a consequence of chronical IL-6 treatment as shown by our group previously (Steiner et al. 2003, Cavarretta et al. 2007). There may be several explanations for this apparent discrepancy. One should keep in mind that other cytokines compensate for loss of FGF-2 expression. Nevertheless, after treatment with FGF-2, both cell lines responded with a significant increase in p44/p42 phosphorylation compared to the treated control in the presence of decreased SOCS-3 protein levels. On the other hand, $\mathrm{LNCaP}$ cells overexpressing SOCS-3 showed a decreased $\mathrm{p} 44 / \mathrm{p} 42$ phosphorylation after FGF-2 treatment.

The findings of our study may have considerable clinical implications. Both FGF-2 and SOCS-3 were detected in prostate cancer, and it was shown in experiments using cell lines and patients' material that their expression increases during progression to therapy resistance (Nakamoto et al. 1992, Cronauer et al. 1997, Bellezza et al. 2006, Puhr et al. 2009).

\section{SOCS-3 mRNA and protein are differentially regulated by FGF-2}

FGF-2 regulated SOCS-3 protein expression levels, although mRNA level remained unchanged. One plausible explanation for this finding could be cell line-specific protein stabilisation or increased proteasomal degradation as a consequence of FGF-2 treatment. In order to elucidate the importance of this observation, we extended our treatment time up to 5 days. Consistently, the data were similar and confirmed short-time treatment results. A transient downregulation of SOCS-3 mRNA by IGF1 was also reported (Evans et al. 2007). Thus, peptide growth factors may display different effects on SOCS mRNA and protein expression respectively.

In summary, in the present study, we clearly showed that SOCS-3, which is in part regulated by FGF-2, antagonises the effect of the growth factor by interfering with the activation of the p44/p42 MAPK pathway. SOCS-3 is a multifunctional key protein in many pathways, and there are indications that it has different functions depending on the tumour origin. In a previous study, we showed that sustained downregulation of SOCS-3 leads to increased apoptosis through the activation of the extrinsic and intrinsic apoptosis pathways in prostate cancer cells (Puhr et al. 2009). We also demonstrated that SOCS-3 is highly expressed in castration-resistant prostate cancer patients (Bellezza et al. 2006, Puhr et al. 2009). 
Taken together, due to the involvement of SOCS-3 in many different signalling pathways, it can act as an oncogene or a tumour suppressor, depending on the cellular context. In future studies, the interaction of SOCS-3 with other pathways must be investigated in detail to better understand the role of this pleiotropic protein in cancer development and progression.

\section{Supplementary data}

This is linked to the online version of the paper at http://dx. doi.org/10.1677/ERC-10-0007.

\section{Declaration of interest}

The authors declare that there is no conflict of interest that could be perceived as prejudicing the impartiality of the research reported.

\section{Funding}

Austrian Science Fund FWF - grants W1101, 19933, and 18193 (to Z Culig).

\section{Acknowledgements}

The authors acknowledge Dr Ilaria T Cavarretta for helpful discussions, Gertraud Sierek for excellent technical assistance and Robert Schober for the editorial assistance. The authors thank Dr Wolfgang Doppler for kindly providing the cmycSOCS-3 construct used in the present study.

\section{References}

Acevedo VD, Gangula RD, Freeman KW, Li R, Zhang Y, Wang F, Ayala GE, Peterson LE, Ittmann M \& Spencer DM 2007 Inducible FGFR-1 activation leads to irreversible prostate adenocarcinoma and an epithelialto-mesenchymal transition. Cancer Cell 12 559-571.

Ayala G, Tuxhorn JA, Wheeler TM, Frolov A, Scardino PT, Ohori M, Wheeler M, Spittler J \& Rowley DR 2003 Reactive stroma as a predictor of biochemical-free recurrence in prostate cancer. Clinical Cancer Research 9 4792-4801.

Bellezza I, Neuwirt H, Nemes C, Cavarretta IT, Puhr M, Steiner H, Minelli A, Bartsch G, Offner F, Hobisch A et al. 2006 Suppressor of cytokine signaling-3 antagonizes cAMP effects on proliferation and apoptosis and is expressed in human prostate cancer. American Journal of Pathology 169 2199-2208.

Ben-Zvi T, Yayon A, Gertler A \& Monsonego-Ornan E 2006 Suppressors of cytokine signaling (SOCS)1 and SOCS3 interact with and modulate fibroblast growth factor receptor signaling. Journal of Cell Science 119 380-387.
Bradford MM 1976 A rapid and sensitive method for the quantitation of microgram quantities of protein utilizing the principle of protein-dye binding. Analytical Biochemistry 72 248-254.

Bugler B, Amalric F \& Prats H 1991 Alternative initiation of translation determines cytoplasmic or nuclear localization of basic fibroblast growth factor. Molecular and Cellular Biology 11 573-577.

Burke WM, Jin X, Lin HJ, Huang M, Liu R, Reynolds RK \& Lin J 2001 Inhibition of constitutively active Stat3 suppresses growth of human ovarian and breast cancer cells. Oncogene 20 7925-7934.

Cavarretta IT, Neuwirt H, Untergasser G, Moser PL, Zaki MH, Steiner H, Rumpold H, Fuchs D, Hobisch A, Nemeth JA et al. 2007 The antiapoptotic effect of IL-6 autocrine loop in a cellular model of advanced prostate cancer is mediated by Mcl-1. Oncogene 26 2822-2832.

Cronauer MV, Hittmair A, Eder IE, Hobisch A, Culig Z, Ramoner R, Zhang J, Bartsch G, Reissigl A, Radmayr C et al. 1997 Basic fibroblast growth factor levels in cancer cells and in sera of patients suffering from proliferative disorders of the prostate. Prostate 31 223-233.

DeMarzo AM, Nelson WG, Isaacs WB \& Epstein JI 2003 Pathological and molecular aspects of prostate cancer. Lancet 361 955-964.

Deo DD, Axelrad TW, Robert EG, Marcheselli V, Bazan NG \& Hunt JD 2002 Phosphorylation of STAT-3 in response to basic fibroblast growth factor occurs through a mechanism involving platelet-activating factor, JAK-2, and Src in human umbilical vein endothelial cells. Evidence for a dual kinase mechanism. Journal of Biological Chemistry 277 21237-21245.

Dey BR, Furlanetto RW \& Nissley P 2000 Suppressor of cytokine signaling (SOCS)-3 protein interacts with the insulin-like growth factor-I receptor. Biochemical and Biophysical Research Communications 278 38-43.

Dorkin TJ, Robinson MC, Marsh C, Neal DE \& Leung HY 1999 aFGF immunoreactivity in prostate cancer and its co-localization with bFGF and FGF8. Journal of Pathology 189 564-569.

Evans MK, Yu CR, Lohani A, Mahdi RM, Liu X, Trzeciak AR \& Egwuagu CE 2007 Expression of SOCS1 and SOCS3 genes is differentially regulated in breast cancer cells in response to proinflammatory cytokine and growth factor signals. Oncogene 26 1941-1948.

Freeman KW, Gangula RD, Welm BE, Ozen M, Foster BA, Rosen JM, Ittmann M, Greenberg NM \& Spencer DM 2003 Conditional activation of fibroblast growth factor receptor (FGFR)1, but not FGFR2, in prostate cancer cells leads to increased osteopontin induction, extracellular signal-regulated kinase activation, and in vivo proliferation. Cancer Research 63 6237-6243.

Gioeli D, Mandell JW, Petroni GR, Frierson HF Jr \& Weber MJ 1999 Activation of mitogen-activated protein kinase associated with prostate cancer progression. Cancer Research 59 279-284. 
Giri D, Ropiquet F \& Ittmann M 1999 Alterations in expression of basic fibroblast growth factor (FGF) 2 and its receptor FGFR-1 in human prostate cancer. Clinical Cancer Research 5 1063-1071.

Giri D, Ozen M \& Ittmann M 2001 Interleukin-6 is an autocrine growth factor in human prostate cancer. American Journal of Pathology 159 2159-2165.

Hadari YR, Gotoh N, Kouhara H, Lax I \& Schlessinger J 2001 Critical role for the docking-protein FRS2 alpha in FGF receptor-mediated signal transduction pathways. PNAS 98 8578-8583.

Hammacher A, Thompson EW \& Williams ED 2005 Interleukin-6 is a potent inducer of S100P, which is up-regulated in androgen-refractory and metastatic prostate cancer. International Journal of Biochemistry \& Cell Biology 37 442-450.

Hart KC, Robertson SC, Kanemitsu MY, Meyer AN, Tynan JA \& Donoghue DJ 2000 Transformation and Stat activation by derivatives of FGFR1, FGFR3, and FGFR4. Oncogene 19 3309-3320.

Hart KC, Robertson SC \& Donoghue DJ 2001 Identification of tyrosine residues in constitutively activated fibroblast growth factor receptor 3 involved in mitogenesis, Stat activation, and phosphatidylinositol 3-kinase activation. Molecular Biology of the Cell 12 931-942.

Hatziapostolou M, Polytarchou C, Katsoris P, Courty J \& Papadimitriou E 2006 Heparin affin regulatory peptide/ pleiotrophin mediates fibroblast growth factor 2 stimulatory effects on human prostate cancer cells. Journal of Biological Chemistry $\mathbf{2 8 1}$ 32217-32226.

Hernandez S, de Muga S, Agell L, Juanpare N, Esgueva R, Lorente JA, Mojal S, Serrano S \& Lloreta J 2009 FGFR3 mutations in prostate cancer: association with low-grade tumors. Modern Pathology 22 848-856.

Hobisch A, Ramoner R, Fuchs D, Godoy-Tundidor S, Bartsch G, Klocker H \& Culig Z 2001 Prostate cancer cells (LNCaP) generated after long-term interleukin 6 (IL-6) treatment express IL-6 and acquire an IL-6 partially resistant phenotype. Clinical Cancer Research 7 2941-2948.

Hodge DR, Hurt EM \& Farrar WL 2005 The role of IL-6 and STAT3 in inflammation and cancer. European Journal of Cancer 41 2502-2512.

Ishikawa H, Tsuyama N, Liu S, Abroun S, Li FJ, Otsuyama K, Zheng X, Ma Z, Maki Y, Iqbal MS et al. 2005 Accelerated proliferation of myeloma cells by interleukin-6 cooperating with fibroblast growth factor receptor 3-mediated signals. Oncogene 24 6328-6332.

Kamura T, Maenaka K, Kotoshiba S, Matsumoto M, Kohda D, Conaway RC, Conaway JW \& Nakayama KI 2004 VHL-box and SOCS-box domains determine binding specificity for Cul2-Rbx 1 and Cul5-Rbx 2 modules of ubiquitin ligases. Genes and Development 18 3055-3065.
Klein B, Tarte K, Jourdan M, Mathouk K, Moreaux J, Jourdan E, Legouffe E, De Vos J \& Rossi JF 2003 Survival and proliferation factors of normal and malignant plasma cells. International Journal of Hematology 78 106-113.

Komyod W, Bohm M, Metze D, Heinrich PC \& Behrmann I 2007 Constitutive suppressor of cytokine signaling 3 expression confers a growth advantage to a human melanoma cell line. Molecular Cancer Research 5 271-281.

Kwabi-Addo B, Wang J, Erdem H, Vaid A, Castro P, Ayala G \& Ittmann M 2004 The expression of Sprouty1, an inhibitor of fibroblast growth factor signal transduction, is decreased in human prostate cancer. Cancer Research 64 4728-4735.

Leung HY, Dickson C, Robson CN \& Neal DE 1996 Over-expression of fibroblast growth factor-8 in human prostate cancer. Oncogene 12 1833-1835.

Mohammadi M, Honegger AM, Rotin D, Fischer R, Bellot F, Li W, Dionne CA, Jaye M, Rubinstein M \& Schlessinger J 1991 A tyrosine-phosphorylated carboxy-terminal peptide of the fibroblast growth factor receptor (Flg) is a binding site for the $\mathrm{SH} 2$ domain of phospholipase C-gamma 1. Molecular and Cellular Biology 11 5068-5078.

Muddasani P, Norman JC, Ellman M \& van Wijnen AJ 2007 Basic fibroblast growth factor activates the MAPK and NFkappa B pathways that converge on Elk-1 to control production of matrix metalloproteinase- 13 by human adult articular chondrocytes. Journal of Biological Chemistry 282 31409-31421.

Nakamoto T, Chang CS, Li AK \& Chodak GW 1992 Basic fibroblast growth factor in human prostate cancer cells. Cancer Research 52 571-577.

Neuwirt H, Puhr M, Cavarretta IT, Mitterberger M, Hobisch A \& Culig Z 2007 Suppressor of cytokine signalling-3 is up-regulated by androgen in prostate cancer cell lines and inhibits androgen-mediated proliferation and secretion. Endocrine-Related Cancer 14 1007-1019.

Nicholson SE, De Souza D, Fabri LJ, Corbin J, Willson TA, Zhang JG, Silva A, Asimakis M, Farley A, Nash AD et al. 2000 Suppressor of cytokine signaling-3 preferentially binds to the SHP-2-binding site on the shared cytokine receptor subunit gp130. PNAS 97 6493-6498.

Ornitz DM, Xu J, Colvin JS, McEwen DG, MacArthur CA, Coulier F, Gao C \& Goldfarb M 1996 Receptor specificity of the fibroblast growth factor family. Journal of Biological Chemistry 271 15292-15297.

Polnaszek N, Kwabi-Addo B, Peterson LE, Ozen M, Greenberg NM, Ortega S, Basilico C \& Ittmann M 2003 Fibroblast growth factor 2 promotes tumor progression in an autochthonous mouse model of prostate cancer. Cancer Research 63 5754-5760.

Powers CJ, McLeskey SW \& Wellstein A 2000 Fibroblast growth factors, their receptors and signaling. Endocrine-Related Cancer 7 165-197. 
Puhr M, Santer FR, Neuwirt H, Susani M, Nemeth JA, Hobisch A, Kenner L \& Culig Z 2009 Down-regulation of suppressor of cytokine signaling-3 causes prostate cancer cell death through activation of the extrinsic and intrinsic apoptosis pathways. Cancer Research 69 7375-7384.

Putz T, Culig Z, Eder IE, Nessler-Menardi C, Bartsch G, Grunicke H, Überall F \& Klocker H 1999 Epidermal growth factor (EGF) receptor blockade inhibits the action of EGF, insulin-like growth factor I, and a protein kinase A activator on the mitogen-activated protein kinase pathway in prostate cancer cell lines. Cancer Research 59 227-233.

Ropiquet F, Giri D, Lamb DJ \& Ittmann M 1999 FGF7 and FGF2 are increased in benign prostatic hyperplasia and are associated with increased proliferation. Journal of Urology 162 595-599.

Ropiquet F, Giri D, Kwabi-Addo B, Mansukhani A \& Ittmann M 2000 Increased expression of fibroblast growth factor 6 in human prostatic intraepithelial neoplasia and prostate cancer. Cancer Research 60 4245-4250.

Savinainen KJ, Saramaki OR, Linja MJ, Bratt O, Tammela TL, Isola JJ \& Visakorpi T 2002 Expression and gene copy number analysis of ERBB2 oncogene in prostate cancer. American Journal of Pathology 160 339-345.

Spangenburg EE 2005 SOCS-3 induces myoblast differentiation. Journal of Biological Chemistry 280 10749-10758.

Spiotto MT \& Chung TD 2000 STAT3 mediates IL-6-induced growth inhibition in the human prostate cancer cell line LNCaP. Prostate 42 88-98.

Steiner H, Godoy-Tundidor S, Rogatsch H, Berger AP, Fuchs D, Comuzzi B, Bartsch G, Hobisch A \& Culig Z 2003 Accelerated in vivo growth of prostate tumors that up-regulate interleukin-6 is associated with reduced retinoblastoma protein expression and activation of the mitogen-activated protein kinase pathway. American Journal of Pathology 162 655-663.

Takeuchi R, Matsumoto H, Okada H, Hori M, Gunji A, Hakozaki K, Akimoto Y \& Fujii A 2007 Differences of cell growth and cell cycle regulators induced by basic fibroblast growth factor between nifedipine responders and non-responders. Journal of Pharmacological Sciences 103 168-174.
Tuxhorn JA, Ayala GE, Smith MJ, Smith VC, Dang TD \& Rowley DR 2002 Reactive stroma in human prostate cancer: induction of myofibroblast phenotype and extracellular matrix remodeling. Clinical Cancer Research 8 2912-2923.

Udayakumar TS, Stratton MS, Nagle RB \& Bowden GT 2002 Fibroblast growth factor-1 induced promatrilysin expression through the activation of extracellularregulated kinases and STAT3. Neoplasia 4 60-67.

Wang J, Stockton DW \& Ittmann M 2004 The fibroblast growth factor receptor-4 Arg388 allele is associated with prostate cancer initiation and progression. Clinical Cancer Research 10 6169-6178.

Wang J, Thompson B, Ren C, Ittmann M \& Kwabi-Addo B 2006 Sprouty4, a suppressor of tumor cell motility, is down regulated by DNA methylation in human prostate cancer. Prostate 66 613-624.

Wesley UV, McGroarty M \& Homoyouni A 2005 Dipeptidyl peptidase inhibits malignant phenotype of prostate cancer cells by blocking basic fibroblast growth factor signaling pathway. Cancer Research 65 1325-1334.

Wong CP, Bray TM \& Ho E 2008 Induction of proinflammatory response in prostate cancer epithelial cells by activated macrophages. Cancer Letters 27 38-46.

Xia L, Wang L, Chung AS, Ivanov SS, Ling MY, Dragoi AM, Platt A, Gilmer TM, Fu XY \& Chin YE 2002 Identification of both positive and negative domains within the epidermal growth factor receptor $\mathrm{COOH}$ terminal region for signal transducer and activator of transcription (STAT) activation. Journal of Biological Chemistry 277 30716-30723.

Yadav A, Kalita A, Dhillon S \& Banerjee K 2005 JAK/STAT3 pathway is involved in survival of neurons in response to insulin-like growth factor and negatively regulated by suppressor of cytokine signaling-3. Journal of Biological Chemistry 280 31830-31840.

Yang F, Strand DW \& Rowley DR 2008 Fibroblast growth factor-2 mediates transforming growth factor-beta action in prostate cancer reactive stroma. Oncogene 27 450-459.

Yasumoto H, Matsubara A, Mutaguchi K, Usui T \& McKeehan WL 2004 Restoration of fibroblast growth factor receptor 2 suppresses growth and tumorigenicity of malignant human prostate carcinoma PC-3 cells. Prostate $61236-242$. 